\title{
obituary
}

\section{Michael Abercrombie}

Mr Michael Abercrombie FRS, Director of the Strangeways Research Laboratory, Cambridge, who was distinguished for his contributions to the study of cell locomotory behaviour and malignant invasion in tissue culture, died of cancer on 28 May 1979 after a protracted illness. The importance of his scientific achievement lies as much in his almost single-handed establishment of new general aproaches to the problems of development and malignancy as in the details of his own work. His goodhumoured courtesy, fairness and deep humanity captured the devotion of all he met throughout the world.

Michael Abercrombie was born on 14 August 1912, at Rhyton Dymock, Gloucestershire. His father, Lascelles Abercrombie, was a distinguished poet and literary critic who later became the Goldsmith Reader at Oxford. In 1931 Michael Abercrombie obtained a Hastings scholarship to read zoology at Queen's College, Oxford. One of his tutors there was Gavin de Beer, an immensely erudite descriptive embryologist, who stimulated his interest in experimental embryology. He left Oxford in 1934 with a 1st in zoology and moved to the Strangeways Laboratory in Cambridge to work with C.H. Waddington who had a dazzling and fascinating influence on him. Here he experimented on the primitive streak in early blastoderms and, for this work, he obtained an Oxford BSc which was then a research degree.

Shortly before the war, he met M.L. Johnson (Jane) at Birmingham University and they were soon married. They spent the war years working together on the degeneration and regeneration of peripheral nerve, a programme of work supervised by J.Z. Young and chosen because of its possible usefulness to wartime surgery. This work was largely carried out in the Anatomy Department at Birmingham but the laboratory was not equipped and Michael had to surrender his superannuation in order to raise money for apparatus. I believe that at the same time he sold his wife's car; her sacrifice surpasses that of Faraday's wife whose linen gown was shredded into strips in order to insulate a coil!

After the war, he took up a lectureship in the Anatomy Department at University College London where J.Z. Young held the chair and here he became reader in charge of the Sub-department of Embryology and eventually, in 1959, a second chair was created for him within the department. Under his leadership, the subdepartment soon became a major centre for embryology in Britain and out of it came the Journal of Embryology and Experimental Morphology. In 1962 he became Jodrell Professor of Zoology at University College and, in 1970, he succeeded Honor Fell as Director of the Strangeways Laboratory from which he was to retire in the autumn of 1979.

Michael Abercrombie was a founder member of the London Embryologists' Club which first met in November 1947 and which later became the British Society for Development Biology. He was also elected a Fellow of the Institut International d'Embryologie in 1956, a Fellow of the Royal Society in 1958 and was awarded an honorary doctorate by the University of Uppsala in Sweden in 1977.

The main theme of Abercrombie's research was a study of how signals which control locomotory behaviour are communicated between cells. He early noticed that the Schwann cells associated with regenerating peripheral nerve stumps in culture cease to move once the stumps have met and he soon performed the classic experiment of using time lapse cinematography to observe the behaviour of locomoting fibroblasts in a culture consisting of two confronted explants of chick heart tissue. In 1950 he was joined in this work by Joan Heaysman and they started the publication of their results in 1953.

These papers were of enormous importance to biology. They released a powerful new technique - the careful quantitative analysis of cell behaviour and simultaneously revealed what has since proved to be probably the most important of the behavioural reactions, contact inhibition of locomotion. With Jack Ambrose, Abercrombie made a cytological study of contact inhibition in both normal and malignant cells and the resulting paper became the ninth most highly quoted in cancer in the period 1960-1975. It initiated an interest in the relation of the cell surface to malignancy which swept the cancer research world.

Until his retirement, he continued to work on models of malignant invasion in culture with Joan Heaysman and Pat Stephenson but, in the mid sixties, the emphasis of his research changed to the machinery of cell locomotion and Sue Pegrum, an electron microscopist, joined the group at University College. Later, when I moved with him to the Strangeways Laboratory, this subject became the main interest of our small research group. Among the topics more peripheral to the central theme, he continued his early primitive streak experiments with Ruth Bellairs, worked on liver regeneration with R.D. Harkness and investigated collagen formation during wound healing with D.W. James.

Michael Abercrombie's scientific ability was impressive. His command of techniques and comprehensive knowledge of the literature were matched only by his imaginative insight, his dogged pursuit of a problem and his high standard of objective evidence. His reluctance to speculate or to place too simple an interpretation on his results often made his papers hard going for the reader and sometimes led to the oversimplification or outright misrepresentation of his work by others.

In scientific discussion, as always, he was just and courteous. He spoke little (in his own opinion he was almost neurotically shy) and preferred to listen, but what he did say was very carefully thought out and well worth close study. He was extraordinarily knowledgeable not only within science (he read a minimum of 50 papers in preparation for each lecture to his students) but also in music, painting, literature and politics, rivalling, although he would never have agreed, the breadth of learning which he so admired in his friends Lancelot Hogben, J.B.S. Haldane and Gavin de Beer. Nevertheless, he remained totally modest and unassuming, never averse to humble tasks, even after attaining international distinction. He was patiently tolerant of shortcomings in others and was acutely sympathetic towards oppressed or unfortunate people, spending much of his time unobtrusively helping them.

These, then, were the qualities which have endeared Michael Abercrombie to so many. Perhaps his most extraordinary achievement is that, without exception, all who knew him well had a profound respect and fond regard for him. He overcame the hardships and endured the irony of his final illness with typical stoicism and good humour.

Graham A. Dunn

\section{Julia Bell}

Julia Bell, FRCP died on 26 April 1979, shortly after her 100th birthday. She was one of the pioneers of human genetics and worked at University College London throughout her life.

Like many human geneticists she came into the subject from mathematics, which she had studied at Girton, and she worked as Karl Pearson's statistical assistant from 
1908 to 1914. At about that time K.P. became increasingly aware of the lack of medical expertise in the Galton Laboratory, and it was at his suggestion that Julia Bell qualified as a doctor. Applied statistics and medicine formed the basis of the work for which she is famous, the collections of human pedigrees published under the general title of the Treasury of Human Inheritance. This was the first systematic attempt to document the distribution of human disease within families, and so anxious was Karl Pearson that these pedigrees should be most scrupulously recorded that in his 1912 preface he promised that the 'Treasury' would contain 'no reference to theoretical opinions.' In Julia Bell he found a fellow perfectionist with regard to the data, but by the $1920 \mathrm{~s}$ a few mild opinions were obviously more acceptable. Subsequently Dr Bell wrote analytical articles which are among the classic papers of the subject. Perhaps the most notable are her 1940 paper on consanguinity rates and her 1937 paper with J.B.S. Haldane on the linkage between the genes for colour-blindness and haemophilia. This was the first demonstration "that the principles of linkage which have been worked out for other animals also hold good for man.'

Dr Bell was on the staff of the Galton Laboratory until 1965 when she of ficially retired, at the age of 86 ! Although never Galton Professor of Human genetics herself she outlived the first three, Pearson, Fisher and Penrose, and in her 90 s was still sufficiently concerned with the Laboratory to remonstrate with the Galton Professor when she felt it to be necessary! She was a supporter of the Women's Suffrage Movement, but never a militant. She was something rarer, one of the first generation of women to engage in professional scientific research, and to do it supremely well.

Elizabeth B. Robson

\section{N.D. Riley}

Norman Denbigh Riley, CBE, who died on 26 May 1979 at the age of 88 was an eminent British entomologist with a high reputation as a lepidopterist and as a tireless and effective worker in the interests of international entomology.

For nearly a quarter of a century he was head (Keeper) of the Department of Entomology in the British Museum (Natural History), and between the 1930s and 1950s saw it transformed from a dusty insect storehouse into a modern research institution. We may claim for him, as such a modest man would never claim for himself, that he was largely responsible for the high regard in which the Department of Entomology is still undoubtedly held internationally.

Fifty years ago service to one's country was more esteemed than it is today, and in 1932 when E.E. Austen (a military man himself) retired as Keeper of Entomology he was instrumental in securing Riley's appointment as his successor in preference to F.W. Edwards. Riley had served in the army with distinction for the whole length of the Great War, rising to the rank of Captain, whereas Edwards - the scientifically more qualified man - had been a non-combatant pacifist through his Quaker convictions.

While Riley might have been fortunate at this juncture in his life, his promotion to Keeper was to prove amply justified. He had a taste for administration unusual in entomologists and soon became the architect both figuratively and almost literally (as he did much to plan the present departmental building) of an expanding Department of Entomology. During his Keepership the insect collections grew enormously, often through purchase of specialized collections negotiated by Riley and there were comparable increases in the department staff. Riley himself was a gregarious man, and when his staff became large enough he encouraged more contact amongst them by organizing annual staff dinner dances, which proved a popular innovation in an otherwise rather stuffy museum. During the Second World War he organised the evacuation of large parts of the collection and the library to safe quarters, and their return after the war, although he remained in South Kensington. The CBE was conferred on Riley in 1952.

In his Presidential Address to the Royal Entomological Society, Riley amused his audience by recalling when his small daughter was overhead to say "My daddy doesn't work - he goes to the Museum." In this she had caught Riley's character to a nicety, for to him work and pleasure were synonymous, and long after his official retirement in 1955, until his death in fact, he was a regular visitor to his beloved collection of butterflies in the Museum.

Butterflies were Riley's life-long scientific interest, and one that he was able to indulge professionally from the time of his appointment to the Museum staff as an Assistant in 1911 (which followed on the heels of a short period learning entomology while a demonstrator at the nearby Imperial College). It was not until his return from the war in 1919 , however, that Riley published his first modest paper, describing some new Brazilian species of butterflies, but from then on he published regularly for over half a century, his bibliography of about 400 works including books, editorials and reviews as well as scientific papers. His scientific contributions to lepidopterology will be assessed in specialist journals, but mention should be made of his book written in collaboration with his friend Lionel Higgins entitled $A$ Field Guide to the Butterflies of Britain and Europe: although only published in 1970 this has already run through several editions and has been issued in nine languages.

Riley lived as a boy in South London, where he was born in the suburb of Tooting on 20 September 1890 and where he was educated at Harlington School, Balham and Dulwich College. A neighbour was Richard South, doyen amongst British Lepidopterists, and it was he who stimulated Riley's childhood interest in butterflies - so effectively as it turned out that Riley even on the eve of his death was discussing butterfly nomenclature with a friend.

Butterflies in spite of, or perhaps because of, their popularity have always had their problems with scientific names, and Riley was inexorably drawn into the intricacies of nomenclature, with the result that he served for 15 years (from 1950 to 1965 ) on the International Commission for Zoological Nomenclature. As commision Secretary and member of its editorial Committee he was the mastermind behind the current edition of the International Code of Zoological Nomenclature and bore much of the burden of its production.

He was prominent also in international biology through his election to the International Entomological Congresses and his long connection with Congress organization. For a time Riley served as Chairman of the Entomological Section of the International Union of Biological Sciences. Responsibilities of this kind involved him in occasional distant travel, but most of his collecting was done in Europe. At home Riley's energies were poured into Society affairs. He was a Fellow of the Royal Entomological Society for 67 years (elected in 1912). For the last twenty of these, until his death he held the rare distinction of a Life Fellowship. Riley served on the Society's council (1921-23, 1929-30), and as its Secretary (1926-29, 1941-51), Treasurer (1939-40) and President (1951-52).

$\mathrm{He}$ belonged to the British Entomological and Natural History Society for an even longer period, having joined as a boy in 1902, and was its President in 1923-24. This Society gave him special links with many amateur specialists who were keen readers of The Entomologist a monthly journal largely devoted to Lepidoptera that Riley owned and edited for thirty-six years (1923-1959). A position he relished was that of organizer over many years of the Verrall Supper, an annual gathering of professional and amateur entomologists; in a long life he missed only two of these occasions and was present at the very first in 1912 .

Norman Riley enjoyed every moment of a hard-working life and was the perfect examplar of those qualities that in a more gentlemanly age were laid down for the conduct of British Museum staff - that they should be "persons of honour, integrity and liberality." $\mathrm{He}$ is survived by his widow, a son and daughter.

Pamela Gilbert 